\title{
Blue Labour or the Political History Blues
}

\author{
Lawrence Black, University of York
}

How does history feature in and explain the British Labour Party's recent past? Labour's current electoral and existential crisis was a toxic blend of the 'Brexit' victory in the EU referendum, electoral collapse in Scotland, fallout from the Chilcot Report into the Iraq War, an internal anti-semitism enquiry and, above all, the stasis of a leader in Jeremy Corbyn who was twice elected by local members (2015 and 2016), but not supported by MPs in the Parliamentary Party. 'The political history blues' less takes sides in these woes than highlights disconnections between the uses of history within the Labour Party and in wider historical practice and writing. It relates recent histories of the left in $19^{\text {th }}-20^{\text {th }}$ century Britain, to the state of modern political history in general and the 'Blue Labour' initiative in particular. As a historiographical intervention, it is not pessimistic - political history is a rich field, if in a methodological malaise - but notes less work identifies itself as 'labour history." Even as, paradoxically, debate about history within Labour was vibrant as the Blue Labour (c.2010-15) project offered a nostalgic rediscovery of Labour's past to reinvigorate the post-Blair party and policy and was stimulated by Corbyn's surprise election. The disjuncture between debates within academic history and about history within the Labour Party is the article's structural pivot. But it argues not for a precise fit and for correlation as much as causation, even a certain opaqueness, in the relationship between the two. For left history, however imperfect the chemistry of segueing academic and activist / policy uses of history, the exercise discloses plenty about both.

\section{Wither Labour History?}

At the British Labour party's centenary in 2000, labour history seemed a robust sub-discipline. ${ }^{1}$ It was not at the crux of methodological dispute as it had been a generation before, when Eric Hobsbawm and Gareth Stedman Jones had pitted materialist and linguistic approaches against each other by applying them to Labour's crisis with Thatcherism. ${ }^{2}$ But notably in Labour's First Century, which dealt with thennovel topics like gender and memory, it remained a vibrant site of historical debate. New Labour generated floods of scholarship on how it governed, its language, political economy, foreign and cultural policy, ideology and how new it was. ${ }^{3}$ And it stimulated work inflected by a New Labour paradigm on earlier periods — on charismatic, controversial leaders or when it had seemed out of touch with a New Britain. ${ }^{4}$

But since 2000, such confidence has evaporated. Rumours of labour history's death circulated, obituaries were readied-was labour history, history? ${ }^{5}$ This 
was related to disappointment with New Labour, opposition to the Iraq War from 2003, the familiar drift into economic crisis from 2008 and loss of office in 2010. Fair to say, Blair, Brown and Ed Miliband attracted a number of friendly (i.e. left) critics - from the outset a re-grouped Marxism Today derided New Labour's language and fanciful embrace of the market. ${ }^{6}$ Would even revisionist Tony Crosland have found New Labour congenial? ${ }^{7}$ (Ralph) Miliband-esque jeremiads in which Labour compromised an electorate baying for a more red-blooded party were common. ${ }^{8}$ Historian Ross McKibbin was amongst New Labour's most trenchant critics from the pages of the London Review of Books.

Such criticism was something labour historians would recognise in Labour's past. But this seemed less a divergence, more a qualitative break-as New Labour's political mission took it elsewhere and labour history struggled for vitality. In its origins and classical form labour history was not a singular school. It combined an interest in Labour and trade unions, and engaged with social histories of the working class_classically in Labour "movement" writers like G.D.H. Cole. Its politics were invariably partisan, if a broad church, including Henry Pelling's institutional focus and Ralph Miliband's holding of Labour to a socialist standard. The lines between political activist discussion and historical writing were regularly blurred-as history was wielded to extol or attack contemporary Labour actions. There was no singular relationship between politics and the discipline. Labour historians tended to have peculiar politics compared to the wider electorate and were less beholden to them than the party had to be. But the field in general shared a national focus and conventional approach (sourced from conferences, leading figures), if its subject was less established. Social history from the 1970 s did bring to labour history an interest in marginal, alternative activities and lifestyles, outside the official movement. But fewer historians working on Labour politics, the working class or collateral areas describe themselves as labour historians. They appeared a post-industrial rare breed. It was not, as the Blue Labour initiative showed, that there was a lack of creative interest in the party's past. The past provided vital material and context to segue with present-day policy-making, but not in ways that much involved or animated labour historians.

The wider left offered little respite. Deindustrialisation continued to transform the working class, with trade union membership slowly falling-and for historians who base politics on such social forces, this meant there was little strange in the death, or dearth, of labour history. The Co-op announced its biggest financial loss in 2013, lost control of the Co-op Bank to US hedge funds and saw its Chairman (until June 2013), Methodist Minister and Labour Councillor Paul Flowers, resign amidst drug and sex scandals. The Socialist Workers' Party, having survived the end of the Cold War and its interactions with George Galloway, faced allegations of rape cover-up from 2010. Its response, a defence of Leninism and dismissal of feminism, bourgeois legality and the internet (where much debate was conducted), made Tariq Ali's depiction of the far left in Redemption look decidedly less satirical. 
As capitalism fractured, taking Labour down with it, the left (excepting Occupy) clung to Ken Loach's 2013 film The Spirit of '45, as a response to austerity.'

Labour history has lost several founding grandees and intellectual keystones: Hobsbawm, (Baron) Asa Briggs (Vice President of the Society for the Study of Labour History until 2016) and of a younger generation, Duncan Tanner. And figures from its wider orbit, cultural points of reference like Richard Hoggart and Stuart Hall, have also passed. ${ }^{10}$ Key archives have encountered funding woes - the wonderfully refurbished People's History Museum, Women's Library and Ruskin College. The Society's journal, Labour History Review, could seem pre-occupied with debating the recently deceased (1920-91) Communist Party of Great Britain (CPGB). CPGB research boomed as UK and international archives opened after the Cold War and generated some insightful studies into Communist and far left identity and networks. ${ }^{11}$ But methodological innovation was not common, and the boom can also be read as evidence of the conceptual stasis and limited ambitions of labour history that newly available resources were so readily seized upon. ${ }^{12}$ Labour history's difficulties were not unique to Britain; just as anxieties about social democracy's "retreat" or questions like "what's left of the left?" were to be found across western democracies. ${ }^{13}$ Labnet, European Labour historians' listserv since 1997, cited hugely diminished traffic as a reason for its 2015 closure. $^{14}$

This was a crisis long in gestation. In 1982 History Workshop had added "and feminist" to "a journal of socialist historians"; in 1995 it dropped the subtitle altogether. In 2002, the Welsh journal Llafur morphed from "Labour" to "people's" history. ${ }^{15}$ In 1994 McKibbin—updating Hobsbawm's 1978 question "The Forward March of Labour Halted?" - had asked "is it still possible to write Labour History?" Its certainties and categories challenged by post-modernism, feminism, anthropology, and Marxism's collapse, McKibbin answered not without equivocation, but affirmatively. ${ }^{16}$ In 2010 Richard Price turned in a virtual obituary when he reviewed the field on the Society's fiftieth anniversary. Labour History had from the $1960 \mathrm{~s}$ been an innovator. In 2010, Price found "much of what I read was familiar... conventional and staid." "If a Rip van Winkle labour historian had gone to sleep in 1980 and woken up in the labour history world of 30 years later," Price felt, "it would not take long for him to get up to speed on the historiography, he would not have to learn a new vocabulary." Compared to "the glory days of the 1960 s and 1980s," Price encountered "little, too of the conceptual experiment and debate." Nonetheless, Price commended a "transnational direction for the field." Historians should recognise how in attentiveness to the marginalised, it had incubated categories_-gender, race — that were now undercutting it and "give thanks to labour history for helping pare the post-modernist crusade against social history down to size" in the 1990s (a battle Price was vocal in). Nonetheless, "the move away from materialism as a basic framework of historical analysis" and "fundamental shifts in... the working class" undermined "labour history as it had previously been practiced" and "progressive politics as it had previously been known." "As class went 
into demise in the political world" and "'new' Labour ... worked to cut its ties to its earlier history," traditional labour history's prospects were diminished——it was no longer a magnet for innovative scholarship." 17

Price rather overstated the situation. Many commentators had already cited a global turn in Labour history. ${ }^{18}$ In the USA (Labor History, International Labor and Working-Class History), Australia (Labour History), Canada (Left History) and other western democracies the field seemed robust. Class, the categorical mainstay of labour history, remains central to debate. ${ }^{19}$ It never receded as much as some of its defenders protest, and has profited too from a post-postmodern re-turn to stress the social context of politics, non-discursive forces and material culture. Competitor categories have meant Class Struggles, but it has many advocates. ${ }^{20}$ The complaint that labour historians were "too easily satisfied by material explanations" was not new. Nor did it mean that cultural approaches could not enlighten studies of the shop floor, as Saunders's forensic study of car workers (a cultural version of Jonathan Zeitlin's early industrial relations work) does. ${ }^{21}$

\section{Whither Labour History?}

But few would argue with Price that the political axis of history has shifted away from labour history. The politics of history and method are now more hotly debated in cultural and transnational histories of sex, gender, emotions, consumerism or political culture. These historiographical trends have enlivened Labour History, if producing histories less likely to identify as Labour first-and-foremost. The trajectory of Labour's First Century contributors Francis, Brooke, Fielding and Lawrence discloses much. Martin Francis' work on gender and emotional history has moved away from politics. Labour (and labour history) awaits a full historical treatment of their masculinity. The politics of sexuality on the left have been subjected to Stephen Brooke's and Lucy Robinson's analyses. And Julia Laite reminds us that work on prostitution is as much labour history as the history of sexuality. ${ }^{22}$ Other prolific Labour historians have shifted to popular culture to source understandings of politics - Steve Fielding on plays, novels and TV and Matthew Worley on punk and fanzines. ${ }^{23}$ Part of the story here was twentieth century history catching up with groundbreaking works, particularly on nineteenth century popular politics by Jon Lawrence and others.

As political culture has emerged as an analytical topic and approach, traditional party-centred histories (Conservative no less than Labour) have lost favour. The frame has been much more party competition and interaction-as Thorpe's local study of Parties at War stressed. ${ }^{24}$ Studies of conservatism (lower-case c) have flourished by focusing less on the party (upper case) than on race and empire, culture, gender, New Right ideology, transnational perspectives, and micro-histories of local activism. ${ }^{25}$ But the shift should not be overstated. Much political history remains traditional, institutional, party-centric: Thorpe's history of Labour entered its fourth edition in 2015 and there have been numerous studies of the 1960s Wilson 
governments (suggesting its stock is rising). ${ }^{26}$ And even where exploring roads less travelled, like Griffiths's study of the countryside or Whiting's of taxation, a party optic persists. ${ }^{27}$

Yet the trajectory is clear-with party politics understood not just in its own terms but as part of a wider culture, Jon Lawrence has considered its conduct, performance and technologies in the interplay of media, voters and politicians, and how politics was consumed and perceived by the public. ${ }^{28}$ With the import of party not taken-for-granted or privileged, how it has related to the activism of social movements and NGOs has been vital in this re-situating of politics. ${ }^{29}$ Another part of the appeal of social movements was to find alternative paradigms for politics in places other than establishment bastions like Labour. This also accounts for some of the interest in the CPGB, ILP and far left. ${ }^{30}$

Consumption has been another historiographically rich area. A resurgence in Co-op studies chimed with a hope it was The Hidden Alternative to the economic crisis - mutual, voluntary models were also in vogue. ${ }^{31}$ The Co-op's 2009 Blowin' in the Wind TV ads were the first time Bob Dylan licensed his music for British ads. As noted earlier, these prospects were disappointed — another illustrative mismatch with historians' energies. Still, the Co-op was exploited to explore working-class life, business, and comparatively - and politically, as Gurney shows, as newer forms of consumer social movement activism challenged its claim to speak for the consumer. $^{32}$

Others focused on the consumption of politics, concurrent with the rise of "spin" and delving into Labour's reception and reputation. Many show New Labour's presumed novelty had a longer history. Wring documents Labour's publicity and marketing since 1918; Beers its intimate relationship and concern with inter-war modern media; Thomas the biases of popular newspapers since $1945 .{ }^{33}$ A continuity here was Labour's longstanding conception of the press's power to frame debate, critically or favourably. There was then little news in the media's 2015 role to labour historians. The Murdoch and Rothermere press, decreased print circulation offset online, remained powerful. McKibbin argued "the press and television were responsible for deficit fetishism" becoming viewed as an economic norm rather than political choice, and portrayed Ed Miliband "more viciously than they did Kinnock in 1992.” Although Gaber argues the Daily Mail attack landed less of a blow on "Red Ed" (the red label having lost its lustre post-Cold War) than on 'Odd Ed," the out-of-touch embodiment of a metropolitan, professional political class. $^{34}$

Besides consumption, imperial and transnational agendas have both left traditional labour history looking parochial, and have proven a creative stimulus. Eley's epic connects the left to other European progressive movements. ${ }^{35}$ Comparative work has offered a way out of parochial Britishness, for instance in Favretto's work on Italy and Hilson's on Sweden. ${ }^{36}$ Work on ethnicity, empire and the labour diaspora has ranged across Zionism; representations of the Attlee's imperial ad- 
ministration; London as a hub of 1930s anti-imperial radical networks; and Hyslop's study of J.T. Bain, the Scottish syndicalist, racist and founder of socialism in South Africa. ${ }^{37}$ The hybrid of gender and transnational politics accounts for the recent popularity of Ellen Wilkinson. ${ }^{38}$ If views from beyond Labour, from the periphery not just metropole, have stimulated, so have those deploying longer-established "from below" and local approaches. ${ }^{39}$

Another vibrant area and one which has retained a more conscious engagement with present-day Labour is the history of ideas. It remains important to re-assessments of the late nineteenth century mix of ideas and hopes that, besides the push for state action, Bevir argues Labour originated in. And it has offered a varied and rich rethinking of mid-century Labour revisionism. Butler's work on Michael Young's focus on community and family, signals revisionism's varieties. ${ }^{40}$ Works bordering political science offer historical perspective too. Bale's study of Ed Miliband's leadership notes the usual leftward swing, but rare achievement of unity after an election defeat. It now seems this unity after 2010 was born of limited authority, and relinquished in the 2015 leadership contest that disclosed differences between members and MPs, cathartically releasing suppressed frustrations with New Labour. Work on the unstable history of Labour membership since the 1990s, the sociology of Corbyn's supporters, and party structures also sheds light. Also prescient here seems Toye's version of Tony Benn's case that New Labour was an elite project, "the smallest party in history." ${ }^{11}$

\section{The Political History Blues?}

Part of Labour history's malaise is the broader impasse of political history. Recent overarching interpretations of modern British history-Offer, Edgerton, Savage, Todd- - have cast politics more as a recipient than agent of analysis. All profoundly political books, they are not chiefly about politics. ${ }^{42}$ At the self-consciously paradigm exploring 2015 Retbinking Modern British Studies Conference in Birmingham, politics as a direct topic was scarcely to be found, except on a final day panel entitled, "Whatever happened to political history?"

It is not just an increasing consciousness that politics has often been regarded pejoratively, or that anti-politics is a strong cultural strain. ${ }^{43}$ Rather it is that the methodological developments spurred by engagement with cultural and linguistic turns and Foucaldian ideas of the variegated nature of power in the "new political history" of the 1990s and 2000s have stalled. Its interest in the discursive invention and symbolic imagining of politics has been pared back by the reassertion of the social dimension and limits to political action; its interest in the wider reception and perception of politics-its performance and communication-persists. Critiqued for its propensity towards anthropological description and neglect of the hierarchies of power or the agency of the state, the "new political history" is no longer new, certainly for those interested in producing more than a transcript of official documents and their terminologies. ${ }^{44}$ The "new political history"- despite 
its best instincts - was always semi-detached from political science, to the detriment of both. Such methodological action as there is, in areas like digital access to sources, is replete with practical implications, but with its theoretical import more tentatively broached. ${ }^{45}$

It is not, then, that novel work on modern British political history is absent, but that by comparison with, say Germany or the US, or earlier periods, it seems methodologically quiescent, unconfident, or to take its cues from elsewhere. ${ }^{46}$ Surely other scholars do not look to it as a methodological touchstone in the way they did in the heyday of the "new political history"? The political zeitgeist has left political history. Readman's 2009 account betrays no little range of output, but a field methodologically placid, complacent, stale even. ${ }^{47}$ As noted around consumption and transnationalism (and studies of Communism), the supply of research is plentiful, but more self-consciously demanding approaches, rarer. Albeit evident in Crowcroft's study of Labour elites that applies a "high politics" approach (at odds with labour instincts) and in Robinson's cultural approach that assesses party identities in the context of wider British culture. ${ }^{48}$

Robinson segues the practice of political history with Labour's understanding of its past. She holds that since the 1980s all political parties have grappled with their self-identity and traditions — at one with British culture's penchant for heritage and the relativism of post-modernism, whereby history taught lessons or popular memory depicted it in contemporary terms. History as a discrete force, to which parties had a distinct approach and revealed deep trends or difference to the present, instead became a battleground of current concerns. Marquand likewise argues that political culture has become presentist, and glib about but nostalgic for the past (like Ishiguro's memory-dissolving mist in The Buried Giant). Integral to the construction of "Old Labour" was a certain version of history, one that New Labour wished not to forget, but to distance itself from. In the process, it erased much. Fielding sees much the same in Loach's Spirit of '45. ${ }^{49}$

Whether Blue Labour demonstrates the ongoing value Labour puts by the past or has made present-centred selections from it, what it certainly shows is that history remained a vital political resource for debate and the detachment between historians and Labour. The evacuation of orthodox labour history signalled both its historiographical exhaustion and Labour's political project heading in different directions, and Blue Labour - in that it was preoccupied with Labour's past, but not with labour history-exemplified this. Debates were conducted at the forefront of Labour politics, but in terms unfamiliar to Labour history. Pace Robinson, one might query how uniquely or strictly historical Labour was previously, or how intimate Labour historians and Labour's visions were (more often critically engaged than intimate friends). Conversely, as Jobson argues, if more pronounced in Blue Labour, nostalgia was not a novel cultural proclivity for Labour to be exhibiting. ${ }^{50}$

Corbyn's emergence seems a UK variant on Syriza in Greece, Bernie Sanders in the USA or Podemos in Spain, but also speaks to the resilience of a 
more recognizably "labour history" version and vision of the past amongst some grassroots supporters. Not that the left has a monopoly on the past. Blue Labour released a degree of nostalgia for what New Labour might have been, and Corbyn's election has animated narratives of battling the Militant Tendency in the 1980s. Former leader Neil Kinnock invoked the party's parliamentary purpose since 1906 in a speech emboldening Corbyn's truculent MPs against the weight the Corbyn support-group Momentum put by social movement models and rhetoric. ${ }^{51}$ Such tensions between winning elections, beliefs and extra-parliamentary forces are age-old. The point here is how mobilising the past is risky, if history has different pasts, but remains a highly valued tool in Labour debate. Arguably, all the more so as the speed and spread of social media has enabled nostalgia for a vividly imagined past, displaced historians' authority as a source for this, and disrupted the norms and conduct of political debate. It is also worth remembering that Labour's obsession with its past(s) is not much shared by the electorate.

\section{Blue Labour}

Blue Labour was one of several post-New Labour initiatives-like Progress's The Purple Book and One Nation-in the wake of the 2010 election and the economic crisis. It eschewed New Labour's reverence for markets and shared its skepticism about "old Labour" and unwillingness to revert to the state. The aim was to move beyond the New-Old binary-recognising that what had been novel about New Labour had become centralised and establishment. Blue signalled a nostalgic sense of loss and a conservative tinge (blue is associated with the Conservative Party), to court controversy. The liberal-skeptic, faith-based alternatives to state and market proposed by its key thinker, Lord (from 2011) Maurice Glasman, coincided with Philip Blond's Red Tory (an influence on "Big Society" rhetoric). ${ }^{52}$ Blue Labour made limited headway outside (and inside) Labour confines. By 2011 the group had disbanded, the "blue" tag rendered toxic by Glasman's comments on engaging the far right and in May 2011's Progress that Labour said too little about immigration and ought "to put the people of this country first." ${ }^{33}$ But its debates and ideas retained influence on the Jon Cruddas-led policy review. One Nation (another provocative title, borrowing from Disraeli), which Cruddas inked with leading Blue Labourite Jonathan Rutherford, exhibited numerous tropes of Blue Labour's understanding of past and present: the influence of Glasman and Karl Polanyi; of patriotism; conserving working-class community and family against market disruptions to which New Labour had become habituated; and, like The Purple Book, pre-distribution, decentralisation and mutualism. ${ }^{54}$ Miliband was close to many of these networks.

This article makes no particular claims for Blue Labour's significancesome see it as a fleeting efflorescence now extinct, others as a persistent influence on policy, especially in the context of "Brexit" (2016) and the Scottish independence referendum (2014), given its interest in community, nation and Englishness. ${ }^{55}$ What Giddens saw in both Blue Labour and One Nation in 2013 as "more than a hint of 
nostalgia for a world that has disappeared, never to return" had in "Brexit" become a future that some Blue Labourites could embrace. ${ }^{56}$ What is of interest here are the ways in which it understood and used Labour's history as ammunition or as a premise for policy-making. This sounds like an internal Labour dialogue or a relief at re-engaging with history, even nostalgia, after New Labour's strictures, but in practice it was more partisan — combatting Red Toryism's view of community and Liberal Coalition involvement. Blue Labour's interests were those of Labour history_class, capitalism, culture, community_-but its theory and approach quite different.

The Blue Labour manifesto was 2011's The Labour tradition and the politics of paradox, assembled by Glasman, Rutherford, Marc Stears (Miliband's speech writer) and Stuart White (like Stears, an Oxford Professor). The first seminar was held at University College, Oxford in October 2010. The Introduction sounded a concern that "Labour had no shared interpretation of its history" which was at odds with many strands that Blue Labour toyed with from Labour's past. On the whole, the e-book maintained a fittingly open tone and showed how live a range of historical questions - about beliefs, radical traditions, means and ends, Cole and Tawney's rehabilitation, Crosland's demotion-were to Labour. On organisation, Stears addressed "issues that mattered enormously to our party's founding generations" and flagged keywords like "fellowship" and "relational" to convey how Labour ought to practice its values. Other tropes included: defending working-class self-help and mutual traditions against imposed global markets; a "new economy" post-2008, sustainable, humane (supporting the "living wage" campaign); and decentralising state power-differentiating Blue from New. Labour had become, Rutherford estimated, too "disconnected from the ordinary everyday lives of the people" and needed to re-establish this relationship. If not, "Labour is at risk of losing England." Others stressed the English radical tradition-Cruddas sang the virtues of Robert Blatchford and E.P. Thompson, White invoked "the spirit of Tom Paine." Its silences were as notable-Europe and EU liberal ideals were scarcely mentioned, mostly to note Labour as an exception to social democratic norms. Values of family, home and nation gave this a nostalgic, even conservative air. It embraced this seeming paradox, describing its project as "radical conservatism," that preserving what seems lost or threatened was as important as change in mobilising support and in resisting commodification. Joining Britons' long struggle against dispossession and the alienating impact of markets, "radical conservatism shares this sense of loss, a degradation of human labour under the conditions of a profit-maximising capitalism" as White put it. ${ }^{57}$

For Glasman, Labour had become too liberal-dominated, focused on change delivered by state-level experts, rather than true to its pluralist past, grounded in the authentic reciprocal relationships of working-class community. He stressed that Labour was neither secular nor divided by religion, unlike much European social democracy. Reestablishing a community base was not just nostalgia, but meant 
the London Citizens, churches and US style community-organising for the "common good" (Arnie Graf, a Chicago organiser, worked for Labour until 2013). Glasman held the Attlee governments and Crosland responsible for this turn in Labour's thought and practice from the varieties of Cole, Laski, and the Co-ops to a centralised state that could redistribute and enable the good life. Jose Harris has argued Crosland's target in The Future of Socialism (1956) was less austere Fabians than Laski's case that personal liberty and democracy were incompatible with capitalism. It wasn't just that Crosland seemed to have reached a truce with capitalism, as New Labour's take on free markets in the 1990s was about enabling participation in globalisation rather than protection from it. Much of this distaste for liberalism was its penchant for general moral principles. "Labour values are not abstract universal values such as 'freedom' or 'equality,', Glasman asserts. Crosland's focus on ends rather than means, like New Labour's embrace of globalisation, left it talking in abstract terms that might "apply in any country ... rather than developing the specific language from within the political traditions of our own country." 58

Polanyi, the Hungarian political economist and 1930s WEA lecturer is Glasman's lodestar. He offered an economic anthropology of resistance to being corralled by market practices, which resonated anew after discredited state socialism, and as neo-liberalism faltered. ${ }^{59}$ In The Great Transformation (1944), Polanyi argued that historically, self-regulating markets were enforced by the state rather than a natural order, and whilst wealth might be redistributed, the more fundamental challenge was limiting the commodification of labour and everyday life. To this end, autonomous civic, voluntary, religious and democratic life were vital means. Resistance to capital was thus in a reciprocal relationship with it (good for it, in short), however much market utopians willed otherwise. This was about individuals, but not market individualism or the abstract individual rights of secular liberalism. Like Polanyi (and Stears), Glasman highlighted Cole's Guild socialism as evidence of pluralism and the value of work. ${ }^{60}$

Glasman's earlier work, Unnecessary Suffering, underlines these points. He identifies labour as a cultural and political activity (referencing Biernacki's work) and plots the trade-offs between market and society in Britain from land enclosures, poor relief, labour de-skilling through to the key modern paradigms of the Second World War and the New Left and Right. ${ }^{61}$ Glasman's leitmotiv is the desire to preserve human labour and relationships as virtues — with values not just value as price or commodity. His resistance to commodification draws on Aristotle and Catholic social theology besides usual left suspects. ${ }^{62}$ He praises West Germany's social market economy-its worker representatives, subsidiarity, co-determination, vocational training, strong local government and banking-over more abstract economic philosophies and policies. Balancing, regulating, and stabilising market forces requires such non-contractual relationships, public goods, social knowledge creators (schools, libraries), legal and democratic institutions, to preserve and renew. For Glasman the paradox is that "socialism is a precondition of a viable capitalism," or 
as he puts it in The Labour Tradition, "a condition of a sustainable capitalism." 63

Stears' work relates closely to labour history interests. His first book explores debates between US progressive nationalists (Lippman, Weyl) to extend state power, and UK socialist pluralists (Tawney, GDH Cole, Laski) to challenge it. More than their differences over the state or how they map onto present-day communitarian or associational theory (like Paul Hirst's work), it was the shared values, aims of industrial democracy and tackling poverty, and terms of this trans-Atlantic debate that impress Stears. In their robust openness to others and negotiation of adverse social and political circumstances, he saw a counter to utopian-idealist and narrowpessimist theories. Equally, it differentiated Laski and Cole from New Liberalism, wary of 1990 s re-imaginings of a "progressive alliance." ${ }^{44}$ Demanding Democracy is absorbed by how twentieth century American radicals debated a "new kind of politics," conscious that its behaviours might not be ideal for the future society. If explosive, creative action was legitimate to enhance the existing order, this was not a recipe for anything goes. New Left students, labour unions, civil rights campaigners, and progressives weighed up strategy's longer-term impacts on citizen's virtues (a Blue Labour keyword). For Stears, vital for "a democratic theory of political action in non-ideal circumstances is an account of the political virtues needed to shape the right response to those circumstances, a response that has the prospect of improving the democratic order, of bringing the ideal closer to realisation." He wanted to move beyond realist democrats (too accepting of how things are) and deliberative democrats (too idealistic about how they ought to be). It is not hard to see in the book's concern with how radicals then and now sought to both "preserve the best aspects of the prevailing order and ... construct a better, fairer, more inclusive alternative" connections to Blue Labour. ${ }^{65}$

As interventions in philosophy, Stears's works do not always or directly translate into contemporary politics. It's not easy to recognise the radical riskiness or street struggles of Demanding Democracy in Labour. But it is evident in extolling rangy debate and his Institute for Public Policy Research outputs on transcending the market-state dichotomy. ${ }^{66}$ It is also evident in his interest (like Glasman) in London Citizens, a coalition of local community educational, ethnic, religious, trade union groups that built relationships with community organisers often through individual confessional engagement. Such emphases differentiated it from New Labour's campaigning style, policy focus on the global and technocratic state and, in insisting on its organisational potential to exercise political power, from the "Big Society." Stears suggested historians would recognise the focus on place, organisation and relationships in the works of Tawney, Raymond Williams and Raphael Samuel and urged Labour to "remember its own tradition."

This develops the idea that Crosland's revisionism in the 1950s took a raft of Labour thinkers out of Labour's repertoire, along with more obvious targets like ascetic Fabianism. In practice it elevated the Fabian faith in expert applied knowledge to the fore in social democracy. One Nation briefly mentions Michael Young (a 
lacunae in Blue Labour's reading of Labour's past, presumably because of his involvement with the SDP, where he set up a Tawney Society) as an advocate of community-level engagement and social movement activism, about which Crosland was warier, but engaged with. Other research on the "Pavement Politics" of housing, roads or playgrounds does suggest Labour was part of the problem, if also that the initiatives and resources of community politics were not as diminished as Blue Labour contends. ${ }^{68}$ But One Nation argues that after 1951 Labour "did not choose the path of social renewal and active democracy" — instead "its politics were championed by the small New Left." ${ }^{\circ 9}$

Rutherford, who has written widely for Soundings on culture, emotion, and masculinity, besides Labour politics, attempts to merge Blue Labour and the first New Left (more indigenous, less influenced by Western Marxist theory).$^{70}$ Both saw English modernity and common culture as radical and conservative and the importance of culture as a political resource. Amongst the New Left's "key figures," Rutherford has Richard Hoggart, who was not an editor of New Left Review or its forerunners and contributed just a four page transcription of a debate with Raymond Williams to it. He notably omits Ralph Miliband, who was closely involved editorially and contributed substantially, often on Labour's shortcomings. One need not read far into The Uses of Literacy to find Hoggart warning of the romanticisation- "the danger of over-stressing the admirable qualities of earlier working-class culture" or leftism which "pities the ... debased worker, whose faults he sees as almost entirely the result of the grinding system which controls him" and "admires the remnants of the noble savage, and has a nostalgia ... for such scraps of them as he thinks he can detect today" - to which both the New Left were and Blue Labour are prone. $^{71}$

The second New Left of Perry Anderson and Tom Nairn was, Rutherford regrets, defined by "the certainty of their own historical analysis." This sits uneasily with some of the cant Rutherford himself wields about the "closing of a specific historical period," centred on shifts in political economy in 1979 and 2008. One could object that this is very certain and privileges political economy over culture (pace the New Left), and it's unclear that neoliberalism perished in 2008. Its intellectual pretensions "detached the second new left from common English culture." Except, of course, that Nairn was Scottish and wrote extensively on Scottish nationalism - a topic about which Blue Labour, despite the independence referendum, its 2015 general electoral meltdown, and concern with Englishness, is oddly reticent. ${ }^{72}$ Rutherford regards this detachment as one of the causes of the New Right's triumph over social democracy in the 1970s. Even New Labour suffered from the New Left's elitism, leaving the "third way" to accommodate itself to economic liberalism in the 1990s. Like the New Left, Blue Labour claims to have the right ideas. 


\section{Blue Labour's Critics: Do its Politics and History Add Up?}

The New Left analogy has been treated warily elsewhere. The radical patriotism of Blue Labour and One Nation would likely have found a welcome from E.P Thompson's vision of eighteenth and nineteenth century popular politics and in his battle against the value put on imported Marxist theory by the second New Left. True, Mike Kenny reckons, but Thompson would have been guarded against a sense that this modern version "signalled too great an accommodation with political forms of conservatism" and was insufficiently part of a "transformative politics in the here-and-now." And Blue Labour was divided in just this way over "Brexit," with Rutherford most positive about what he saw as a defeat for liberalism and opportunity to press native and cultural-identity concerns. Others-and one suspects that First New Left — whilst no fans of EU supra-state institutions, were suspicious of a less internationalist, "little England" agenda. ${ }^{73}$

Other critics have been legion. Tribute, Blue Labour would have it, to its energising of debate. It was such a mesh of ideas and eclectic traditions - anarchosydicalism anyone? - that critics had plenty of choice. Progress were sceptical of Blue Labour's nostalgia and ability to resist globalisation. To its credit, The Labour Tradition aired debate — notably Jackson questioning how contaminated Labour was by liberalism or egalitarianism and showing its Gladstonian inheritance. Liberalism's persistent presence across parties and political culture, much as Blue Labour might regret it, was discernible from the nineteenth century and constitutional reform to neo-liberalism. ${ }^{74}$ Blue Labour conceived itself as post-New Labour, recovering an identity forsaken for slick PR, but if "radical conservatism" was "an antithesis to features of New Labour," White wondered what was the synthesis? Others saw blue and new more in tandem. ${ }^{75}$

Much debate has been conducted in the journal Renewal. Finlayson found "making sense" of Glasman and his emergence as an "intellectual guru" hard to square with Labour traditions and culture. Glasman would relish such charges, and who prior to 2010 was discussing Polanyi in Labour circles? Even Glasman's practice of delivering speeches, then published online, marked him apart. Finlayson reckoned the conservatism, paradoxically, of Labour party culture was likely to limit his impact. Conservatism in the sense that issues of national identity, race, religion and the emotive ways Glasman discussed them ran against the grain of Labour's inherited language and (electoral) instincts; in raising these issues Blue Labour hived them off from wider debate. Or in the sense that Corbyn's election was a return to something familiar, showing Labour less bound by than moved by its past. Rooksby is impressed by Blue Labour's case that Labour had more of an affinity with conservatism than liberalism and the abstract ideals of Fabians, Crosland and New Labour had led it astray. Quite, if also worth noting how parts of the New Right were less market utopians than opposed to this sort of liberal establishment expertise and pursuit of change through abstract principles. Rooksby also contends socialism has always been transformative and future-focused-and in this, shares much (more 
than Blue Labour allows) with liberal traditions. Socialism has not lacked idealistic thinkers. And whilst Crosland is critiqued for rejecting the idea that capitalism was inherently unstable and exploitative, Blue Labour themselves regard these as contingent features of speculative finance, rather than systemic. ${ }^{76}$

Blue Labour's sociology was not lost on critics. In a pivotal phrase, Glasman conceived of Labour as a "marriage between a decent working-class dad and an educated middle-class mum," in which from the 1940s the latter gained the upper hand. Such gendered language was noted in Helen Goodman's critique of Blue Labour's sexism. Of The Labour Tradition's 24 pieces, 21 are by men. ${ }^{77}$ Graf revealed his amazement at the party's difficulties finding a minimum wage worker to meet Miliband. McKibbin turned on fellow Oxford academics, concerned that "the difference between the life-experience of those who 'advise' Miliband and those who vote UKIP seems now unbridgeable.” McKibbin stressed external forces as problematic for Labour - the challenge of Scottish nationalism, the EU-but also its insecure social base: "Glasman and the other proponents of Blue Labour ... call for an 'authentic' working-class party uninfected by bourgeois social liberalism (no pussy-footing on the issue of race) ... the class they wish to win back, the white working class, is in steady decline." Labour might crave a "Britain in which class and party loyalty trumped everything else," but that was (always) very wishful thinking. ${ }^{78}$

Other historians have weighed in. Jon Lawrence notes the tradition of using history as a political resource: foundation myths, heroic biographies, and belief in an inexorable forward march pepper Labour's past. Blue Labour's understanding of Labour made by nineteenth century mutualism and losing its way in the $1940 \mathrm{~s}$ as middle-class liberal intellectuals and the central state came to dominate, was, for Lawrence, another myth. Or at best a reductive narrative of complex processes and factors. He reminds Blue Labour that not all turn-of-the-century working-class mutual associations were pro-Labour or even "political"-many were Liberal and positive about state intervention. The idea that pre-1945 Labour was embedded in local communities, unions and Co-ops was only the case regionally. This gave the sense of a movement, defensive more than oppositional, but was not a model that extended nationwide or into election-winning alliances. In deploying modern media, addressing suburban, patriotic, Anglican and Tory workers and becoming a national party, it was in 1945 that Labour became "Blue," rather than lost its way. Nor was it Labour's post-1945 penchant for statism that eroded self-help traditions-not least, this would accord Labour extraordinary power in shaping popular identities. Other social changes and attitudes_consumerism, privacy, autonomy, apathy-account for the fate of mutual institutions and cultures after 1945, and for popular resistance to state initiatives to engineer civic sociability and participation. All told, besides its geographic limits before 1945, the prospects for developing a nationwide movement or constituency today mean mutualism remains insufficient. ${ }^{79}$

Lawrence is wary of the easy dichotomies Blue Labour drop onto and ex- 
tract from Labour's past. Glasman's sincere attempts to denigrate liberalism in shaping Labour are wishful (well, regretful) politics above all. Bad history does not necessarily translate into bad politics, but it increases the risk. Lawrence is no naysayer and notes how Stears has applied Cole and Laski's values to contemporary individualism and choice, but also how this allows for the liberalism and anti-mutual instincts Blue Labour professes aversion to. Stears suggests part of his re-examination of associational pluralism was because "historians continue to overlook or misunderstand the detailed policy positions." No doubt, but political scientists are prone to discount inchoate popular understandings, even disinterest, in policy and politics. There is a whiff of idealism in the notion that people are waiting, listening for politics to present a coherent set of ideas and policies. It is wishful in imagining such a close relationship between politics and people-blasé about what Lawrence terms "the intractability of everyday life," the fluidities of modern culture, persistent "rugged individualism" (Savage's term) or what Kevin Jefferys terms its "anaemic" political culture since 1918. For all the evidence of a politicisation of cultural and civic life since the 1950s, Britain's remains not a very political culture, with good reasons to mistrust politicians. ${ }^{80}$

Equally, Lawrence concludes with a case-derived historiographically from the linguistic turn-for political language's ability to shape popular attitudes. Its power is not infinite-as discussed, it seems fanciful of Rutherford to insist Labour "become the creative meaning maker of the people." But it could influence or contest "common sense" norms — contingent upon its language both resonating with and shifting understandings of popular experience. The point here is less the proximity of politics-citizens relations, than the ordering of their respective agency — and viewing them as interactive and relational. For New and Blue Labour, popular attitudes were fixed and it was politics that had to adapt. New Labour's achievements were couched in terms of existing interests, preconceptions and neoliberal framing-efficiency and aspiration rather than fairness or inclusivity. Whilst electorally successful, this left it politically vulnerable. Lawrence charges New Labour more than Blue here since it could exercise both rhetoric and public policy, but “didn't even try," paling by comparison with Attlee. ${ }^{81}$ But Blue Labour remained beholden to public opinion, for example, on immigration. Whilst it approached individual well-being through communal efforts, it proved reluctant to challenge economic norms after 2010.

Language and narrative even figure in McKibbin's critique of why Labour has been blamed for the 2008 crash and ensuing austerity. "Labour's supposed overspending did not cause what happened in 2008," but, "the Conservatives have succeeded in making people believe their version of events," to justify austerity, downsize welfare, and embed neo-liberalism — not defunct or guilty — as common sense. Liam Byrne's missive on departing the Treasury in 2010, "there is no money left," became New Labour's epigraph. McKibbin accepts that "given the now received view of its record" forged by the coalition, Blair and Brown's successors 
were "always going to have trouble." But "the stance it has adopted, fearful and dominated by the ideas of the city and debased neoliberal economics," made Labour complicit. It "nervously acquiesced in deficit fetishism, and so gave the game to the government," McKibbin adjudges, "Milband and Balls should never have allowed the Tories' claims to go unchallenged." 82 Blue Labour counter that polling showed the message of austerity and deficit-reduction had sunk deep into popular attitudes, but that in essence was the point. Corbyn vowed to question their hold, but could he forge an appropriate language, especially as the paradigm and rhetoric of "Brexit" superseded "austerity"?

The paradox for Blue Labour is that Corbyn's 2015 (and 2016 re-) election as leader demonstrates the multiple, conservative, even liberal-idealist cultures that they had highlighted-Labour remains historically-minded, nostalgic even. And if Blue Labour promoted nostalgia and community-reviving a sense of a labour movement outside as well as inside parliament_-so did the Corbyn support-group, Momentum, by explicitly talking of social movement activism and with an apparently clearer sense of the agency needed to build such a movement. If so, then there are prospects for a revival of traditional Labour history, and its accustomed languages; if less of recapturing the historiographical energies and trends that it fostered, but which have left the original behind. Except-and it is a teasing paradox - that much of the energy of newer political history has been invested in social movements and an analytical approach and focus beyond parliamentary politics. If Labour and historiographical trends have converged we can only provisionally tell if this is more by coincidence or design. It would overlook the evidence of detachment here to assume design, but underplay the vibrancy of political historynotwithstanding its methodological issues and labour's history withering-to presume coincidence. Either way - and with the caveat that this relationship concerns the electorate little-Labour looks set to engage historians for years to come.

\section{NOTES}

${ }^{1}$ Duncan Tanner, Pat Thane and Nick Tiratsoo, eds., Labour's First Century (Cambridge: Cambridge University Press, 2000); Stefan Berger, ed., Mitteilungsblatt des Instituts für die Geschichte der sozialen Bewegungen 27 (2002).

${ }^{2}$ Eric Hobsbawm, The Forward March of Labour Halted? (London: Verso, 1981); Gareth Stedman Jones, "Why is the Labour Party in a mess?" in Languages of Class (Cambridge: Cambridge University Press, 1983). 
${ }^{3}$ Colin Hay, The Political Economy of New Labour (Manchester: Manchester University Press, 1999); Richard Little and Mark Wickham-Jones, eds., New Labour's Foreign Policy: A new moral crusade? (Manchester: Manchester University Press, 2000); Stephen Bayley, Labour Camp (London: Pan Books, 1998); John Harris, The Last Party: Britpop, Blair and the Demise of English Rock (London: Harper, 2003); Mark Bevir, "New Labour: a study in ideology," British Journal of Politics and International Relations 2, no. 3 (2000); Anthony Giddens, The Third Way and its Critics (Cambridge: Polity, 2000); Steven Fielding, The Labour Party: Continuity and Change in the Making of 'New' Labour (Basingstoke: Palgrave, 2003); James Cronin, New Labour's Pasts (London: Routledge, 2004).

${ }^{4}$ David Howell, MacDonald's Party (Oxford: Oxford University Press, 2002); Lawrence Black, The Political Culture of the Left in affluent Britain, 1951-64: Old Labour, New Britain? (Basingstoke: Palgrave, 2003).

${ }^{5}$ John McIlroy, "Waving or drowning? British Labour History in troubled waters," Labor History 53, no. 1 (2012).

${ }^{6}$ Marxism Today (Nov. / Dec. 1998).

${ }^{7}$ Dick Leonard, ed., Crosland and New Labour (Basingstoke: Palgrave, 1998).

${ }^{8}$ Richard Seymour, "Bye Bye Labour," London Review of Books (23 April 2015); David Coates, "Labour after New Labour," British Journal of Politics and International Relations 15, no. 1 (2013).

9 Tariq Ali, Redemption (London: Chatto \& Windus, 1991).

${ }^{10}$ John McIlroy, "Asa Briggs and the emergence of Labour History in post-war Britain" in The Age of Asa: Lord Briggs, Public life and History in Britain since 1945, ed. Miles Taylor (Basingstoke: Palgrave, 2015); Andrew Edwards and Chris Williams, eds., The Art of the Possible, Politics and Governance in Modern British History, 1885 1997: Essays in Memory of Duncan Tanner (Manchester: Manchester University Press, 2015).

${ }^{11}$ Gidon Cohen, Andrew Flinn and Kevin Morgan, Communists and British Society, 1920-91 (London: Rivers Oram, 2007); Geoff Andrews, The Shadow Man: at the beart of the Cambridge spy circle (London: IB Tauris, 2015); Celia Hughes, Young Lives on the left: 1960s Activism and the Liberation of the Self (Manchester: Manchester University Press, 2015).

${ }^{12}$ Fielding predicted the opening of the archives might produce a flood of histories, drowning out the CPGB's marginal status. Steven Fielding, "British Communism: Interesting but irrelevant?" review of Shop Floor Citizens: Engineering Democracy in 1940s Britain, by James Hinton, Labour History Review 60, no. 2 (1995): 122.

${ }^{13}$ John Callaghan, The Retreat of Social Democracy (Manchester: Manchester University Press, 2000); James Cronin, George Ross and James Schoch, eds., What's left of 
the left (Durham: Duke University Press, 2011).

14 "Labnet," Social History Portal, accessed 4 September 2015, http://www.socialhistoryportal.org/labnet; email Aad Blok, D. Mayer, 22 April 2015.

${ }^{15}$ History Workshop 13 (1982); History Workshop Journal 39 (1995): iii-iv, 241-242; History Workshop Journal 40 (1995): 271-272.

${ }^{16}$ Ross McKibbin, "Is it still possible to write Labour History?" in Challenges to Labour History, ed. Terry Irving (Sydney: University of New South Wales Press, 1994).

${ }^{17}$ Richard Price, "Histories of Labour and Labour History," Labour History Review 75, no. 3 (2010): 265-268.

${ }^{18}$ Marcel Van Linden, "Labour History: the old, the new and the global," African Studies 66, nos. 2-3 (2007).

${ }^{19}$ Selina Todd, The People: The rise and fall of the working Class, 1910-2010 (London: John Murray, 2014); Mike Savage, Identities and Social Change in Britain since 1940 (Oxford: Oxford University Press, 2010).

${ }^{20}$ Patrick Joyce, The Social in Question (London: Routledge, 2002); Richard Biernacki, The Fabrication of Labor (Berkeley: University of California Press, 1995); Dennis Dworkin, Class Struggles (London: Routledge, 2006); Geoff Eley, A Crooked Line (Ann Arbor: University of Michigan Press, 2005).

${ }^{21}$ William H. Sewell, "Towards a post-materialist rhetoric for labor history" in Rethinking Labor History, ed. Lenard Berlanstein (Chicago: University of Illinois Press, 1993), 17; Jack Saunders, "The British Motor Industry 1945-77: How workplace cultures shaped labour militancy" (PhD diss., University College London, 2015).

${ }^{22}$ Lucy Robinson, Gay Men and the Left in post-war Britain (Manchester: Manchester University Press, 2007); Stephen Brooke, Sexual Politics: Sexuality, Family Planning and the British Left from the 1880s (Oxford: Oxford University Press, 2011); Julia Laite, "(Sexual) Labour Day," Notches (blog), 30 April 2014, http://notchesblog.com/2014/04/30/sexual-labour-day/.

${ }^{23}$ Matt Worley, "Punk, politics and (fan)zines 1974-84," History Workshop Journal 79 (2015); Steven Fielding, State of play: British politics on screen, stage and page, from Trollope to The Thick of it (London: Bloomsbury, 2014).

${ }^{24}$ Andrew Thorpe, Parties at War: Political Organisation in Second World War Britain (Oxford: Oxford University Press, 2009).

${ }^{25}$ Bill Schwarz, The White Man's World (Oxford: Oxford University Press, 2011); Clarisse Berthezène, Training Minds for the Battle of Ideas: Ashridge College, the Conservative Party and the cultural politics of Britain, 1929-54 (Manchester: Manchester University Press, 2015); Lawrence Black, "Tories and Hunters; Swinton College and the landscape of Conservatism in post-war Britain," History Workshop Journal 77 
(2014); Daniel Stedman Jones, The Masters of the Universe: Hayek, Friedman and the birth of neoliberal politics (Princeton: Princeton University Press, 2012); Anna Von der Goltz and Britta Waldschmidt-Nelson, eds., Inventing the Silent Majority: Conservative Mobilization in America and Western Europe (Cambridge: Cambridge University Press, 2017); Gidon Cohen and Lewis Mates, "Grassroots Conservatism in postwar Britain: a view from the bottom up,” History 98, no. 330 (2013).

${ }^{26}$ Andrew Thorpe, A History of the British Labour Party (Basingstoke: Palgrave, 2015); Glen O'Hara, Helen Parr, eds., Harold Wilson and the Labour Governments of 1964-70 (London: Routledge, 2006); and the 2003 series on foreign, economic and socio-cultural policy by John Young, James Tomlinson and Steven Fielding. ${ }^{27}$ Clare Griffiths, Labour and the Countryside (Oxford: Oxford University Press, 2007); Richard Whiting, The Labour Party and Taxation (Cambridge: Cambridge University Press, 2006).

${ }^{28}$ Jon Lawrence, Electing our masters: The Hustings in British Politics from Hogarth to Blair (Oxford: Oxford University Press, 2009).

${ }^{29}$ Lawrence Black: Redefining British Politics: Culture, Consumerism and Participation 1954-70 (Basingstoke: Palgrave, 2010); Matthew Hilton et al., The Politics of Expertise: How NGOs shaped Modern Britain (Oxford: Oxford University Press, 2013).

${ }^{30}$ Gidon Cohen, The Failure of a Dream: The ILP from Disaffiliation to World War II (London: IB Tauris, 2007); Paul Corthorn, In the shadow of the dictators (London: IB Tauris, 2008).

${ }^{31}$ Anthony Webster et al., eds. The Hidden Alternative: Co-operative values past, present and future (Manchester: Manchester University Press, 2011).

${ }^{32}$ Katrina Friberg, A comparative study of consumer co-operative organisation in Britain and Sweden, 1860-1970 (Vaxjo: Vaxjo University Press, 2005); Nicole Robertson, The Co-operative movement and communities in Britain, 1914-60 (Farnham: Ashgate, 2010); Peter Gurney, "The curse of the Co-ops: Co-operation, the mass media and market in inter-war Britain," English Historical Review 130, no. 547 (2015); Gurney, "The battle of the consumer in post-war Britain," Journal of Modern History 77, no. 4 (2005).

${ }^{33}$ Dominic Wring, The Political Marketing of the Labour Party since 1918 (Basingstoke: Palgrave, 2004); Laura Beers, Your Britain! Media and the making of the Labour Party (Cambridge, Mass: Harvard University Press, 2010); James Thomas, Popular Newspapers, the Labour Party and British Politics (London: Routledge, 2005).

${ }^{34}$ Ross McKibbin, "Labour dies again," London Review of Books (4 June 2015); Ivor Gaber, "The 'othering' of 'Red Ed'," Political Quarterly 85, no. 4 (2014).

${ }^{35}$ Geoff Eley, Forging Democracy: The left in Europe 1850-2000 (Oxford: Oxford University Press, 2002).

${ }^{36}$ Mary Hilson, "Swedish Approaches to the rise of Labour: A British perspec- 
tive," Scandinavian Journal of History 26 (2001); Hilson, Political Change and the rise of Labour in comparative perspective: Britain and Sweden, 1890-1920 (Oslo: Nordic Academic Press, 2006); Ilaria Favretto, The long search for a third way: The British Labour Party and the Italian left since 1945 (Basingstoke: Palgrave, 2003).

${ }^{37}$ David Feldman, "Labour and Zionism" in Jewish History after the Imperial Turn, eds. M. Mandel, E. Katz and Lisa Leff (Bloomington: Indiana University Press, 2016); Charlotte Lydia Riley, “The Confounded Socialists and the Commonwealth Co-operative Society: Cartoons and British Imperialism during the Attlee Government," in Comic Empires, eds. Richard Scully, Andrekos Varnava (Manchester: Manchester University Press, 2016); Susan Pennybacker, From Scottsboro to Munich: Race and political culture in 1930s Britain (Princeton: Princeton University Press, 2009); Jonathan Hyslop, The Notorious Syndicalist (Johannesburg: Jacana Media, 2004).

${ }^{38}$ Matt Perry, 'Red Ellen' Wilkinson: her Ideas, movements and the world (Manchester: Manchester University Press, 2014); Paula Bartley, Ellen Wilkinson (London: Virago, 2014); Laura Beers, Red Ellen: The Life of Ellen Wilkinson, Socialist, Feminist, Internationalist (Cambridge, Mass.: Harvard University Press, 2016). And germane to Blue Labour, see Lawrence Goldman, The life of R.H. Tawney (London: Bloomsbury, 2013).

${ }^{39}$ Laura Schwartz, "What we think is needed is a union of domestics such as the miners have': The domestic workers union of Great Britain and Ireland, 190814," Twentieth Century British History 25, no. 2 (2014); Lewis Mates, The Spanish Civil War and the British Left (London: IB Tauris, 2007); Daisy Payling, "Socialist republic of South Yorkshire: Grassroots activism and left-wing solidarity in 1980s Sheffield," Twentieth Century British History 25, no. 4 (2014).

${ }^{40}$ Mark Bevir, The Making of British Socialism (Princeton: Princeton University Press, 2011); Ben Jackson, Equality and the British Left: A study in Progressive thought, 1900-64 (Manchester: Manchester University Press, 2011); Lise Butler, "Michael Young, the Institute of Community Studies and the politics of kinship," Twentieth Century British History 26, no. 2 (2015).

${ }^{41}$ Tim Bale, Five Year Mission: Labour under Ed Miliband (Oxford: Oxford University Press, 2015); Mark Wickham-Jones and Hugh Pemberton, "Labour's lost grassroots," British Politics 8 (2013); Glen O'Hara, "Who are the Corbynites?” in The Corbyn Effect, ed. Mark Perryman (forthcoming); Richard Toye, "The smallest party in history': New Labour in historical perspective," Labour History Review 69, no. 1 (2004).

${ }^{42}$ Avner Offer, The Challenge of Affluence (Oxford: Oxford University Press, 2006); David Edgerton, Warfare State: Britain, 1920-70 (Cambridge: Cambridge University Press, 2006); Savage, Identities; Todd, The People.

${ }^{43}$ See "Popular Understandings of Politics in Britain, 1937-2015," last modified 8 
February 2012, http://antipolitics.soton.ac.uk; Colin Hay, Why we hate Politics (Cambridge: Polity, 2007).

${ }^{44}$ David Craig, "'High Politics' and the 'new political history'," Historical Journal 53, no. 3 (2010).

${ }^{45}$ Helen McCarthy, "Political History in the digital age," accessed 10 March 2016, http://mei.qmul.ac.uk/blog/items/171361.html.

${ }^{46}$ Forum, "The contours of the political," German History 33:1 (2015); The Democratic Experiment: New Directions in American Political History, eds. Meg Jacobs, William Novak and Julian Zelizer (Princeton: Princeton University Press, 2005); Languages of Politics in $19^{\text {th }}$ Century Britain, eds. David Craig and James Thompson (Basingstoke: Palgrave, 2013).

${ }^{47}$ Paul Readman, "The state of twentieth-century British political history," Journal of Policy History 21, no. 3 (2009).

${ }^{48}$ Hughes, Young Lives on the left, Robert Crowcroft, "The high politics of Labour Party factionalism, 1950-55," Historical Research 81, no. 214 (2008); Emily Robinson, History, heritage and tradition in contemporary British politics (Manchester: Manchester University Press, 2012).

${ }^{49}$ Robinson, History; David Marquand, Mammon's Kingdom (Penguin, 2014); Kazuo Ishiguro, The Buried Giant (London: Faber, 2015); Steven Fielding, "The cultural memory of 1945" (unpublished paper, 2015).

${ }^{50}$ Richard Jobson, "Blue Labour and nostalgia," Renewal 22, nos. 1-2 (2014); Jobson, "A New Hope for an Old Britain? Nostalgia and the British Labour Party's Alternative Economic Strategy, 1970-83," Journal of Policy History 27, no. 4 (2015).

${ }^{51}$ Stuart White, Martin O’Neill, “'The New Labour that wasn't: The lessons of what might have been" in Democracy in Britain: Essays in Honour of James Cornford (London: Institute for Public Policy Research, 2014); Dianne Hayter, Fightback!

Labour's traditional right in the 1970s and 1980s (Manchester: Manchester University Press, 2005); Neil Kinnock, "Neil Kinnock's speech to the PLP 04/07/16," accessed 11 July 2016, https://soundcloud.com/user-152148676/neil-kinnock. ${ }^{52}$ Rowena Davis, Tangled up in Blue: Blue Labour and the struggle for Labour's Soul (London: Short Books, 2011); Philip Blond, Red Tory (London: Faber, 2010). ${ }^{53}$ Bale, Five Year Mission, 52-55; Jonathan Rutherford, "Blue Labour is over but the debate has just begun," New Statesman (29 July 2011).

${ }^{54}$ Jon Cruddas and Jonathan Rutherford, One Nation (London: One Nation Register, 2014), 11-14, 30-34; Mark Wickham-Jones, “The modernising antecedents and historical origins of One Nation Labour” Political Quarterly 84, no. 3 (2013). ${ }_{55}$ Adrian Pabst and Ian Geary, eds. Blue Labour: Forging a New Politics (London: IB Tauris, 2015); Who speaks to England? Labour's English Challenge (London: Fabian Society, 2016). 
${ }^{56}$ Anthony Giddens, “The Future's European," Progress (13 November 2013); Jonathan Rutherford, "Brexit is Labour's future," Progress (10 January 2017).

${ }^{57}$ Maurice Glasman et al., eds., The Labour Tradition and the politics of paradox (London: Oxford London Seminars, 2011), 10, 88, 91, 124, 125, 127, 132, 140.

${ }^{58}$ Maurice Glasman, "Labour as a radical Tradition" in The Labour Tradition, 24; Jose Harris, "Labour's political and social thought" in Labour's First Century, 34, 39.

${ }^{59}$ Chris Hann, Keith Hart, Economic Anthropology (Cambridge: Polity, 2011).

${ }^{60}$ Alan Finlayson, “Making sense of Maurice Glasman,” Renewal 19, no. 2 (2011): $18-24$.

${ }^{61}$ Maurice Glasman, Unnecessary Suffering: Managing Market Utopia (London: Verso, 1996), 5-13, 115-119.

${ }^{62}$ Maurice Glasman, "Politics, employment policies and the young generation," Economia Politica XXX, no. 2 (2013), 139-49; Glasman, "Politics, employment policies and the younger generation," in Together for the Common Good, eds. Nicholas Sagovsky and Peter McGrail (London: SCM Press, 2015).

${ }^{63}$ Glasman, Unnecessary Suffering, 138-142; Glasman, "Labour as a radical tradition," 30-31, 34.

${ }^{64}$ Marc Stears, Progressives, Pluralists and the problems of the state: Ideologies of reform in the US and Britain, 1909-26 (Oxford: Oxford University Press, 2006); see also Bevir, The Making.

${ }^{65}$ Marc Stears, Demanding Democracy: American Radicals in search of a new politics (Princeton: Princeton University Press, 2010), 18, 215-22.

${ }^{66}$ Marc Stears, Everyday democracy: Taking centre-left politics beyond state and market (London: Institute for Public Policy Research, 2011).

${ }^{67}$ Stefan Baskerville and Marc Stears, "London Citizens and the Labour tradition," Renewal 18, nos. 3-4 (2010): 65-70.

${ }^{68}$ Lawrence Black, "Crosland's Consumer Politics" in The Voice of the Citizen Consumer, ed. Kerstin Brückweh (Oxford: Oxford University Press, 2011); David Ellis, "Pavement Politics: Community Action in Leeds, c. 1960-90" (PhD diss., University of York, 2016).

${ }^{69}$ Cruddas and Rutherford, One Nation, 13.

${ }^{70}$ Jonathan Rutherford, "The first New Left, Blue Labour and English modernity," Renewal 21, no. 1 (2013), 9-14; also Jonathan Rutherford, Alan Lockey, eds., Labour's Future (London: Soundings/Open Left, 2010).

${ }^{71}$ Richard Hoggart, The Uses of Literacy (Harmondsworth: Pelican, 1957), 15, 17.

${ }^{72}$ Excepting Ben Jackson, “The political thought of Scottish nationalism," Political Quarterly 85, no. 1 (2014); see Gerry Hassan, Eric Shaw, The Strange Death of 
Labour Scotland (Edinburgh: Edinburgh University Press, 2012).

${ }^{73}$ Michael Kenny, "Faith, flag and the 'first' new Left: E.P.Thompson and the politics of 'one nation'," Renewal 21, no. 1 (2013): 15-23; Rutherford, "Brexit is Labour's future."

${ }^{74}$ Ben Jackson, "Labour History and Glasman's Labour tradition," in The Labour Tradition, 38-41.

${ }^{75}$ Stuart White, "How Conservative should Labour be," in The Labour Tradition, 125-132; Graeme Cooke, "New and Blue" in The Labour Tradition, 133-139.

${ }^{76}$ Finlayson, "Making sense"; Ed Rooksby, "Blue Labour and the limits of social democracy," Renewal 19, no. 3-4 (2011): 104-117.

${ }^{77}$ Helen Goodman in The shape of things to come, ed. John Denham (London: Fabian Society, 2012); Glasman, "Labour," 21.

${ }^{78}$ Arnie Graf, "Labour's failure had little to do with organisers in the field," LabourList, 4 August 2015, http://labourlist.org/2015/08/labours-failure-had-little-to-do-with-organisers-in-the-field/; Ross McKibbin, "Brought to you by the Conservative party," LRB Blog, 11 October 2014, https://www.lrb.co.uk/blog/2014/10/11/ross-mckibbin/brought-to-you-by-theconservative-party/; McKibbin, "Labour vanishes," London Review of Books 36, no. 22 (20 November 2014).

${ }^{79}$ Jon Lawrence, "Blue Labour, One Nation Labour, and the lessons of history," Renewal 21, nos. 2-3 (2013): 6-13; Steven Fielding, Peter Thompson and Nick Tiratsoo, England Arise: Labour and popular politics in the 1940s (Manchester: Manchester University Press, 1995).

${ }^{80}$ Lawrence, "Blue Labour"; Stears, Progressives, 19; Kevin Jefferys, Politics and the People: A History of British Democracy since 1918 (London: Atlantic Books, 2008), 281; Black, Redefining.

${ }^{81}$ Lawrence, "Blue Labour"; Rutherford, "The Future is Conservative" in The Labour Tradition, 94.

${ }^{82}$ McKibbin, "Brought to you"; McKibbin, "Labour Dies again." 